\title{
PENGARUH KEBIJAKAN FISKAL TERHADAP PEMBANGUNAN SEKTOR PERTANIAN KABUPATEN DAN KOTA DI PROVINSI SULAWESI SELATAN
}

\author{
Akhmad*, Noer Azam Achsani**, Mangara Tambunan**, \\ Sumedi Andoyo Mulyo**
}

\begin{abstract}
ABSTRAK
Hasil penelitian tersebut menunjukkan bahwa kebijakan fiskal memberi dampak positif dalam pembangunan pertanian. Oleh karena itu pemerintah daerah kabupaten dan kota di Provinsi Selatan dalam era otonomi daerah dewasa ini, diharapkan dapat mengambil kebijakan fiskal yang dapat mendorong pembangunan pertanian, mengingat sebagaian besar penduduknya berkerja pada sektor pertanian di perdesaan dengan tingkat penghasilan yang rendah, maka penelitian ini bertujuan untuk mengetahui dampak kebijakan fiskal daerah terhadap pembangunan pertanian kabupaten/kota di Provinsi Sulawesi Selatan. Penelitian ini menggunakan model ekonometrika dengan sistem persamaan simultan. Model sistem persamaan simultan yang dibangun terdiri atas 19 persamaan struktural dan 8 persamaan identitas. Model tersebut dibagi ke dalam tiga blok meliputi blok (1) fiskal, (2) permintaan agregat, dan (3) kinerja perekonomian. Hasil penelitian ditemukan bahwa kebijakan fiskal yang dilakukan oleh pemerintah daerah terutama belanja modal sektor pertanian, dapat meningkatkan PDRB sektor pertanain dan pendapatan petani. Sementara belanja modal non pertanian dapat mendorong investasi swasta. Selanjutnya investasi swasta dapat mendorong peningkatan produk domestik regional non pertanian. Disamping itu investasi swasta juga dapat menurunkan angka pengangguran. Sementara kemisikinan dapat diturunkan seiring dengan peningkatan produk domestik regional bruto. Pada sisi lain kebijakan fiskal dengan tujuan untuk meningkatkan pendapatan asli daerah dapat mengurangi investasi swasta. Hal ini menunjukkan bahwa apabila pemerintah daerah memaksakan untuk menggali potensi pajak dan retribusi daerah, dapat menimbulkan high cost economy yang berdampak pada turunnya investasi. Dengan keterbatasan APBD, maka perlu dilakukan efisiensi penggunaan anggaran terutama pada belanja lain-lain, dan belanja barang dan jasa, selanjutnya digunakan untuk meningkatkan belanja modal untuk memperbaiki infrastrukur yang ada.
\end{abstract}

Kata Kunci : Permintaan, Persediaan, Jagung, Ekspor, Impor 


\begin{abstract}
The results of this study indicate that fiscal policies have positive impacts on agricultural development. Therefore, the local governments in Sumatera Selatan province in the era of regional autonomy are expected to take fiscal policy to encourage the development of agriculture, since a large part of the population works in the agricultural sector in rural areas with the lowest income levels. The study aims to determine the impact of fiscal policy on the area of agricultural development district/city in Sumatera Selatan province. This study uses an econometric model with a system of simultaneous equations. Model system of simultaneous equations is constructed consisting of 19 structural equations and 8 identity equation. The model is divided into three blocks covering: (1) fiscal, (2) the aggregate demand, and (3) the economy performance. The study finds that the fiscal policy of the local government, especially the capital spending of agricultural sector can improve GDP and income of farmers while the non-agricultural capital spending can stimulate private investment. Furthermore, private investment can boost regional domestic product of the nonagricultural sector. Besides, private investment can also reduce unemployment rate while poverty can be reduced in line with the increase in regional gross domestic product. On the other side, fiscal policy can increase revenue to reduce private investment. This shows that when local governments are forced to explore the potential of taxes and levies, it can cause high cost economy that lead to the decline of investment. With a limited budget, it is necessary to allocate the efficient use of the budget, especially on other spending, spending on goods and services, which in turn is used to increase capital spending to improve existing infrastructure.
\end{abstract}

Keywords: Demand, Supply, Corn, Export, Import

\section{PENDAHULUAN}

Bagi negara agraris seperti Indonesia, peran sektor pertanian sangat penting dalam mendukung perekonomian nasional, terutama sebagai penyedia bahan pangan, sandang dan papan bagi segenap penduduk, serta penghasil komoditas ekspor nonmigas untuk menarik devisa. Lebih dari itu, mata pencaharian sebagian besar rakyat Indonesia bergantung pada sektor pertanian. Namun ironis sekali, penghargaan masyarakat terhadap sektor pertanian relatif rendah dibandingkan sektor lain, seperti industri, pertambangan, dan perdagangan.

Pada saat perekonomian nasional dilanda krisis, ternyata sektor pertanian terbukti mampu menjadi penyangga ekonomi nasional. Pengalaman krisis multidimensi tahun 1997-1998 memberikan pelajaran berharga betapa strategisnya sektor pertanian sebagai jangkar, peredam gejolak, dan penyelamat bagi sistem perekonomian nasional. Oleh karena itu sektor pertanian merupakan sektor yang berperan penting dalam perekonomian Indonesia. Dikatakan demikian karena 
sepanjang tahun 2000-2009, lebih dari 40 juta jiwa atau sekitar 42 persen angkatan kerja di Indonesia bekerja pada sektor pertanian, dan memberi kontribusi sekitar 15 persen terhadap Produk Domestik Bruto (PDB). Hal tersebut menunjukkan bahwa produktivitas sektor pertanian masih rendah.

Provinsi Sulawesi Selatan adalah provinsi yang terletak di sebelah selatan Pulau Sulawesi dengan luas daratan 45 $574.48 \mathrm{~km}$ persegi, meliputi 20 kabupaten dan tiga kota, dengan jumlah penduduk sebesar 8032551 jiwa berdasarkan sensus penduduk tahun 2010, merupakan provinsi dengan jumlah penduduk terbesar di kawasan timur Indonesia. Sekaligus merupakan provinsi penghasil pengan terbesar yang ada di luar di Pulau Jawa. Kondisi perekonomian kabupaten kota di Propinsi Sulawesi Selatan dewasa ini masih didominasi oleh sektor pertanian, kerena menyediakan lapangan kerja bagi sebagian besar penduduk. Pada tahun 2009 tenaga kerja yang terserap pada sektor pertanian sebesar 49.20 persen, dan penyumbang 29 persen terhadap Produk Domestik Regional Bruto (PDRB).

Meskipun sektor pertanian memberi sumbangsi yang sukup besar terhadap perekonomian nasional maupun Provinsi Sulawesi Selatan, namun peran sektor pertanian terhadap PDB menujukkan tren yang menurun serta produktivitas yang rendah, dibanding dengan sektor non pertanian. Priyarsono, at al, (2005), dan Darsono (2008), mengatakan bahwa kinerja sektor pertanian sejak tahun 1970-2005 menurun, yang ditandai oleh penurunan pangsa sektor pertanian pada PDB, penyerapan dan produktivitas tenaga kerja, serta ekspor produk-produk pertanian.
Sejak tahun 2001 bangsa Indonesia memulai babak baru penyelenggaraan pemerintahan, ketika diberlakukannya Undang-Undang Otonomi Daerah, yaitu Undang-Undang Nomor 22 tahun 1999 tentang Pemerintahan Daerah kemudian direvisi dengan Undang-Undang Nomor 32 tahun 2004, dan Undang-Undang Nomor 25 tahun 1999 tentang Perimbangan Keuangan antara Pemerintah Pusat dan Daerah, yang selajutnya direvsisi dengan UndangUndang Nomor 33 tahun 2004.

Dalam era otonomi daerah dewasa ini, pemerintah daerah memiliki wewenang yang hampir penuh atas penggunaan sumber-sumber fiskal mereka. Pemerintah provinsi dan kabupaten kota, saat ini mengelola sekitar 36 persen dari total pengeluaran publik, dibandingkan dengan kondisi pada pertengahan 1990-an yang hanya berjumlah sekitar 24 persen (World Bank. 2007).

Penelitian kebijakan fiskal dan keinerja sektor pertanian telah banyak dilakukan antara lain; Guimaraes (2010), mengkaji dampak kebijakan fiskal terhadap perekonomian India menggunakan data tahun 1996-2009, Nurudeen dan Usman (2010), menganalisis pengeluaran pemerintah dan pertumbuhan ekonomi di Nigeria, menemukan bahwa kebijakan fiskal dapat memainkan peran yang efektif terhadap perekonomian.

Feltenstein, A., and S. Iwata, (2005) menggunakan data time series tahun 19522096, dengan model vector autoregressive (VAR), menemukan bahwa desentralisasi ekonomi berhubungan positif dengan pertumbuhan output riil di Cina, namun memiliki implikasi yang kurang baik pada tingkat inflasi 
Kebijakan fiskal adalah bentuk intervensi pemerintah untuk mempengaruhi jalannya perekonomian dengan maksud agar keadaan perekonomian tidak terlalu menyimpang dari keadaan yang diinginkan dengan alat (policy instrument variable) berupa Pajak (T), Transfer Pemerintah (Tr), dan Pengeluaran Pemerintah (G). Kebijakan fiskal disebut juga kebijakan anggaran (budgetary policy), dilakukan melalui Anggaran Pendapatan dan Belanja Negara (APBN), (Romer, 2001).

Mehmood and Sadiq (2010) menggunakan data time series 1976-2010, dengan Error Correction Model (ECM), dalam mengananalisis hubungan jangka pendek dan jangka panjang antara pengeluaran pemerintah dan kemiskinan di Pakistan. Menemukan bahwa terdapat hubungan terbalik antara pengeluaran pemerintah dengan tingkat kemiskinan baik dalam jangka pendek maupun jangka panjang. Ditemukan pula bahwa pengeluaran pemerintah pada bidang ekonomi yang efektif dan efisien dapat meningkatkan investasi swasta, perluasan lapangan kerja dan mengurangi kemiskinan

Fan and Rao (2003) mengkaji tentang tren pengeluaran pemerintah di negara berkembang, menemukan bahwa pengeluaran pemerintah pada sektor pertanian dapat mendorong pertumbuhan ekonomi di Afrika dan Asia. Izuchukwu,O. (2011) menggunakan data panel tahun 1986-2007 dalam mengkaji kontribusi

sektor pertanian dalam pembangunan ekonomi di Nigeria, menemukan bahwa ada hubungan positif antara Produk Domestik Bruto (PDB) dengan belanja pemerintah pada sektor pertanian dan investasi asing langsung pada sektor pertanian.
Adeniyi dan Bashir (2011) meneliti dampak investasi publik terhadap pertumbuhan ekonomi di Nigeria. Menggunakan data time series tahun 19702008, menemukan bahwa pengeluaran pemerintah di bidang pertanian, pendidikan, pertahanan, dan jasa secara statistik signifikan, sementara pengeluaran pemerintah di bidang kesehatan, transportasi, dan telekomunikasi secara statistik tidak signifikan.

Yudhoyono (2004), menggunakan model ekonometrika dengan sisitem persamaan simultan, menyimpulkan bahwa kebijakan fiskal memegang peranan penting dalam mendorong pembangunan pertanian, pengurangan kemiskinan dan perekonomian perdesaan. Revitalisasi pertanian dapat dijadikan penggerak pertumbuhan perekonomian di Indonesia.

Sudaryanto dan Rusastra (2006) melakukan kajian tentang kebijakan strategis dalam rangka peningkatan peroduksi pertanian menemukan bahwa; kemampuan sektor pertanian dalam peningkatan produksi dan pengentasan kemiskinan sangat bergantung pada kemampuannya dalam mengatasi kendala pengembangan yang dihadapi, mencakup keterbatasan pengembangan lahan beririgasi, teknologi varietas unggul, ketersediaan anggaran pembangunan, dan penyediaan sistem insentif untuk mendorong peningkatan produksi dan pendapatan petani.

Hasil penelitian tersebut menunjukkan bahwa kebijakan fiskal memberi dampak positif dalam pembangunan pertanian. Oleh karena itu pemerintah daerah kabupaten dan kota di Provinsi Selatan dalam era otonomi daerah 
dewasa ini, diharapkan dapat mengambil kebijakan fiskal yang dapat mendorong pembangunan pertanian, mengingat sebagaian besar penduduknya berkerja pada sektor pertanian di perdesaan dengan tingkat penghasilan yang rendah.

Bertitik tolak pada uraian yang telah diuraikan, maka penelitian ini bertujuan untuk mengetahui dampak kebijakan fiskal daerah terhadap pembangunan pertanian kabupaten/kota di Provinsi Sulawesi Selatan.

I. Blok Fiskal

Penerimaan Daerah

1. Pendapatan Asli Daerah

$$
\text { PADit }=\text { PAJDit }+ \text { RETDit }+ \text { BUMDit }+
$$

PADLit

2. Pajak Daerah

$$
\begin{gathered}
\text { PAJDit }=\mathrm{a} 0+\mathrm{a} \text { 1PGPDit }+\mathrm{a} 2 \text { MTRit }+ \\
\text { a3JKHLit }+\mathrm{a} 4 \text { LPAJDit }+\mathrm{u}
\end{gathered}
$$

parameter estimasi yang diharapkan:

a1, a2, a3, a4 >0

3. Retribusi Daerah

$$
\begin{aligned}
\text { RETDit }= & \text { b0 }+ \text { b1PDRBit }+ \text { b2TPGPDit }+ \\
& \text { b3POPit }+ \text { b4LRETDit }+\mathrm{u} 2
\end{aligned}
$$

parameter estimasi yang diharapkan: b1,

$\mathrm{b} 2, \mathrm{~b} 3, \mathrm{~b} 4>0$

4. Dana Alokasi Umum

DAUit $=\mathrm{c} 0+\mathrm{c} 1$ PADit $+\mathrm{c} 2$ LDKit $+\mathrm{c} 3$ MISKit

$$
+c 4 \text { POPit }+c 5 \text { PNSit }+ \text { u3 }
$$

parameter estimasi yang diharapkan:

$\mathrm{c} 1<0 ; \mathrm{c} 2, \mathrm{c} 3, \mathrm{c} 4, \mathrm{c} 5>0$

Penelitian ini menggunakan model ekonometrika dengan sistem persamaan simultan. Model sistem persamaan simultan yang dibangun terdiri atas 19 persamaan struktural dan 8 persamaan identitas. Model tersebut dibagi ke dalam tiga blok meliputi blok (1) fiskal, (2) permintaan agregat, dan (3) kinerja perekonomian.

Model ekonometrika dengan sistem persamaan simultan yang dibangun adalah:
5. Dana Bagi Hasil

$$
\begin{gathered}
\text { DBHit }=\mathrm{d} 0+\mathrm{d} \text { 1PDRBit }+\mathrm{d} 2 \text { TRENit }+ \\
\mathrm{d} 3 \mathrm{LDBH}+\mathrm{u} 4
\end{gathered}
$$

parameter estimasi yang diharapkan:

$\mathrm{d} 1, \mathrm{~d} 2, \mathrm{~d} 3>0$

6. Total Penerimaan Daerah

TPDit $=$ PADit + DAUit + DBHit + DAKit + 
PLDit

Pengeluaran Daerah

7. Pengeluaran Belanja Pegawai BPGWit $=\mathrm{e} 0+\mathrm{e} 1$ PNSit+e2PADit + e3DAUit +e4LBPGWit+ u 5

parameter estimasi yang diharapkan:

e1, e2, e3, e4 >0

8. Pengeluaran Belanja Barang dan Jasa

$$
\begin{gathered}
\text { BBJit }=\text { f0 }+ \text { f1PADit }+ \text { f2DAUit }+ \\
\text { f3DBHit }+ \text { f4LBBJit }+ \text { u6 }
\end{gathered}
$$

parameter estimasi yang diharapkan:

$\mathrm{f1}, \mathrm{f} 2, \mathrm{f} 3, \mathrm{f} 4>0$

9. Pengeluaran Belanja Modal

$$
\text { BMDit }=\text { BMDSPit }+ \text { BMDSLit }
$$

10. Pengeluaran Belanja Modal Sektor

Pertanian

$$
\begin{aligned}
\text { BMDSPit }= & \text { g0 }+ \text { g1DAKit }+ \text { g2DAUit }+ \\
& \text { g3LBMDSPit }+\quad \mathrm{u} 7
\end{aligned}
$$

parameter estimasi yang diharapkan:

$\mathrm{g} 1, \mathrm{~g} 2, \mathrm{~g} 3, \mathrm{~g} 4,>0$

11. Pengeluaran Belanja Modal NonPertanian

$$
\begin{aligned}
\text { BMDNPit } & =\mathrm{h} 0+\text { h1DBHit }+ \text { h2DAKit } \\
& + \\
& \text { h3LBMDNPit }+ \text { u8 (11) }
\end{aligned}
$$

parameter estimasi yang diharapkan:

h1, h2, h3 >0

12. Belanja Lain-lain Pemerintah (BLL)

BLLit $=\mathrm{i} 0+\mathrm{i}$ 1DAUit $+\mathrm{i} 2 \mathrm{DBHit}+$

i3PADit + i4LBLLit + u9
Parameter estimates of the expected:

i1, i2, i3, i4 >0

13. Total Pengeluaran Pemerintah Daerah

TPGPDit=BPGWit+BBJit+BMDit+BLLit

II. Blok Permintaan Agregat Daerah

1. Pengeluaran Konsumsi Swasta

$$
\begin{aligned}
\text { KONSit }= & \text { j0 }+ \text { j1PDRBit }+ \text { j2BBJit }+ \\
& \text { j3BPGWit } \\
& + \text { j5LKONSit }+ \text { u10 }
\end{aligned}
$$

parameter estimasi yang diharapkan:

$$
\mathrm{j} 1, \mathrm{j} 2, \mathrm{j} 3, \mathrm{j} 5>0 ; \mathrm{j} 4<0
$$

2. Investasi Swasta

$$
\begin{gathered}
\text { INVSit }=\text { k0 }+ \text { k1BMDit }+ \text { k2PADit }+ \\
\text { k3KONS }+ \text { k4LINVSWit }+ \text { u11 }
\end{gathered}
$$

parameter estimasi yang diharapkan:

$\mathrm{k} 1, \mathrm{k} 3, \mathrm{k} 4,>0 ; \mathrm{k} 2<0$

3. Total Pengeluaran Pemerintah

$$
\text { TPGPit }=\text { TPGPDit }+ \text { DDTBLit }
$$

4. Ekspor Daerah

$$
\begin{gathered}
\text { EXPDit }=10+\text { 11NTRPit }+ \text { 12PDRBit }+ \\
\text { 13INFL }+ \text { 14LEXPDit }+\mathrm{u} 12
\end{gathered}
$$

parameter estimasi yang diharapkan:

$$
11,13<0 ; 12,14>0
$$

5. Impor Daerah

$$
\begin{aligned}
\text { IMPDit } & =\mathrm{m} 0+\mathrm{m} 1 \text { PDRBit }+\mathrm{m} 2 \text { KONSit }+ \\
& +\mathrm{m} 3 \text { LIMPDit }+\mathrm{u} 13
\end{aligned}
$$

parameter estimasi yang diharapkan:

$\mathrm{m} 1, \mathrm{~m} 2, \mathrm{~m} 3>0$

6. Ekspor bersih 
$\mathrm{NEXP}=\mathrm{EXPDit}-\mathrm{IMPDit}$

III. Blok Kinerja Perekonomian

1. PDRB Sektor Pertanian

$$
\begin{aligned}
& \text { PDRBSPit }=\text { n0 }+ \text { n1PTKSPit }+ \\
& \text { n2BMDSPit }+ \text { n3LPDRBSPit }+ \text { u14 }
\end{aligned}
$$

parameter estimasi yang diharapkan:

$\mathrm{n} 1, \mathrm{n} 2, \mathrm{n} 3>0$

\section{PDRB Sektor Non Pertanian}

PDRBNPit $=\mathrm{o} 0+\mathrm{o} 1 \mathrm{PTKNPit}+\mathrm{o} 2 \mathrm{INVSit}+$

+ o3KONS it + o4LPDRBTB it + u15

parameter estimasi yang di harapkan:

o1o, o2, o3, o4 >0

3. Produk Domestik Regional Bruto

PDRBit $=$ PDRBSPit + PDRBNPit

4. Penyerapan Tenaga Kerja Sektor

Pertanian

PTKSPit $=\mathrm{p} 0+\mathrm{p} 1 \mathrm{AKK}$ it $+\mathrm{p} 2 \mathrm{BMDSPit}+$

$$
\text { p3LPTKSPit }+ \text { u23 }
$$

parameter estimasi yang diharapkan:

$\mathrm{p} 1, \mathrm{p} 2, \mathrm{p} 3>0$

5. Penyerapan Tenaga Kerja Sektor

non Pertanian

PTKNPit $=\mathrm{q} 0+\mathrm{q} 1 \mathrm{INVSit}+\mathrm{q} 2$ AKKit +

$$
\text { q3LPTKNPit + u24 }
$$

parameter estimasi yang diharapkan:

$\mathrm{q} 1, \mathrm{q} 2, \mathrm{q} 3>0$
6. Total Penyerapan Tenaga Kerja

PTKit $=$ PTKSPit + PTKNPit

7. Pengangguran

$\mathrm{UNEPit}=\mathrm{r} 0+\mathrm{r} 1$ AKKit $+\mathrm{r} 2$ BMDit +

$$
\text { r3LUNEPit }+\mathrm{u} 25
$$

parameter estimasi yang diharapkan:

$\mathrm{r} 1, \mathrm{r} 3>0 ; \mathrm{r} 2<0$

8. Kemiskinan

MISKit $=\mathrm{s} 0+\mathrm{s} 1 \mathrm{PDRBit}+\mathrm{s} 2 \mathrm{POPit}+$

s3PTKit+s4DDTBLit+s5LMISKit+u26

parameter estimasi yang diharapkan:

$$
\text { s2, s5 }>0 ; s 1, s 3, s 4<0
$$

\section{HASIL DAN PEMBAHASAN}

Spesifikasi model yang digunakan dalam penelitian ini telah mengalami beberapa kali modifikasi, karena ditemukan beberapa hasil dugaan yang tidak konsisten dengan teori dan beberapa dugaan parameter yang tidak nyata.

Sehingga akhirnya didapatkan model dengan keragaan hasil pendugaan parameter yang cukup representatif untuk menggambarkan fenomena yang ada pada kabupaten/kota di Provinsi Sulawesi Selatan.

Hasil estimasi model dengan menggunakan metode ekonometrik 2SLS (two stege least square) diperoleh faktorfaktor yang berpengaruh terhadap variabel endogen dalam model, dimana terdapat 19 persamaan struktural, terdiri atas 3 blok secara keseluruhan menunjukkan hasil yang cukup baik. 
Tabel 1. Hasil Estimasi Persamaan Fisikal Daerah

\begin{tabular}{|c|c|c|c|c|c|c|}
\hline \multicolumn{7}{|c|}{ Persamaan Pajak Daerah (PAJD) } \\
\hline Peubah & Estimasi & Prob $>[\mathrm{T}]$ & Elastisitas & Nama Peubah & F-hitung & $\overline{\mathrm{R}^{2}}$ \\
\hline Intercept & -895.2 & 0.1040 & - & Intercept & \multirow{5}{*}{832.09} & \multirow{5}{*}{0.9604} \\
\hline TPGPD & 0.0036 & 0.2348 & 0.1907 & Total pengeluaran pemerintah daerah & & \\
\hline MTR & 0.001 & 0.7911 & 0.0143 & Jumlah kendaraan bermotor & & \\
\hline JMKH & 1.69777 & 0.0011 & 0.1730 & Jumlah kamar hotel & & \\
\hline LPAJD & 0.85192 & $<.0001$ & - & Pajak daerah tahun sebelumnya & & \\
\hline \multicolumn{7}{|c|}{ Persamaan Retribusi Daerah (RETD) } \\
\hline Intercept & -536.323 & 0.1958 & - & Intercept & \multirow{5}{*}{299.40} & \multirow{5}{*}{0.8970} \\
\hline PDRB & 0.00003 & 0.7299 & 0.0142 & Produk domestik regional bruto & & \\
\hline TPGPD & 0.0069 & 0.0251 & 0.3636 & Total pengeluaran pemerintah daerah & & \\
\hline POP & -0.00002 & 0.9838 & -0.0017 & Jumlah populasi & & \\
\hline LRETD & 0.83131 & $<.0001$ & - & Retribusi daerah tahun sebelumnya & & \\
\hline \multicolumn{7}{|c|}{ Persamaan Dana Alokasi Umum (DAU) } \\
\hline Intercept & 53304.24 & $<.0001$ & $\overline{-}$ & Intercept & \multirow{6}{*}{306.86} & \multirow{6}{*}{0.9175} \\
\hline PAD & -0.28029 & 0.1762 & -0.0259 & Pendapatan asli daerah & & \\
\hline LDK & 0.4559 & 0.4741 & 0.0066 & Luas daerah kabupaten/kota & & \\
\hline MISK & 0.110772 & 0.0946 & 0.0366 & Jumlah penduduk miskin & & \\
\hline POP & 0.067244 & 0.0003 & 0.1637 & Jumlah populasi & & \\
\hline PNS & 1.017243 & $<.0001$ & 0.0429 & Jumlah pegawai negeri sipil & & \\
\hline \multicolumn{7}{|c|}{ Persamaan Dana Bagi Hasil (DBH) } \\
\hline Intercept & 2756.456 & 0.0150 & - & Intercept & \multirow{4}{*}{241.81} & \multirow{4}{*}{0.8406} \\
\hline PDRB & 0.0007 & 0.0286 & 0.0701 & Produk domestik regional bruto & & \\
\hline TREN & 2.3732 & 0.9153 & 0.0005 & $\operatorname{Tren}(1.2 .3, \ldots, n)$ & & \\
\hline LDBH & 0.8137 & $<.0001$ & - & Dana bagi hasil tahu sebelumnya & & \\
\hline \multicolumn{7}{|c|}{ Persamaan Belanja Pegawai (BPGW) } \\
\hline Intercept & -3117.36 & 0.4952 & - & Intercept & \multirow{5}{*}{583,24} & \multirow{5}{*}{0.9444} \\
\hline PNS & 3.89653 & 0.0233 & 0.2276 & Jumlah pegawai negeri sipil & & \\
\hline PAD & 0.323036 & 0.0133 & 0.0414 & Pendapatan asli daerah & & \\
\hline DAU & 0.174508 & 0.0292 & 0.2420 & Dana alokasi umum & & \\
\hline LBPGW & 0.548494 & $<.0001$ & - & Belanja pegawai tahun sebelumnya & & \\
\hline \multicolumn{7}{|c|}{ Persamaan Barang dan Jasa $($ BBJ) } \\
\hline Intercept & 215.3115 & 0.9280 & - & Intercept & \multirow{5}{*}{238.20} & \multirow{5}{*}{0.8738} \\
\hline PAD & 0.243074 & 0.0187 & 0.1059 & Pajak daerah & & \\
\hline DAU & 0.041144 & 0.0438 & 0.1940 & Dana alokasi umum & & \\
\hline DBH & 0.093203 & 0.2660 & 0.0564 & Dana bagi hasil & & \\
\hline LBBJ & 0.723246 & $<.0001$ & - & $\begin{array}{l}\text { Belanja barang dan jasa tahun } \\
\text { sebelumnya }\end{array}$ & & \\
\hline \multicolumn{7}{|c|}{ Persamaan Belanja Modal Sektor Pertanian (BMDSP) } \\
\hline Intercept & 3215.575 & $<.0001$ & - & Intercept & & \\
\hline DAK & 0.025847 & 0.3520 & 0.0567 & Dana alokasi khusus & & \\
\hline PDRBSP & 0.001373 & 0.0338 & 0.0975 & PDRB Sektor pertanian & 23.37 & 0.32882 \\
\hline LBMDSP & 0.432886 & $<.0001$ & - & $\begin{array}{l}\text { Belanja modal sek. pertanian tahun } \\
\text { sebelumnya }\end{array}$ & & \\
\hline Persamaan & elanja Moc & I non Pertani & n (BMDNP) & & & \\
\hline Intercept & -8016.31 & 0.0692 & 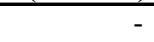 & Intercept & & \\
\hline DBH & 0.613073 & $<.0001$ & 0.2207 & Dana bagi hasil & & \\
\hline DAK & 1.369996 & $<.0001$ & 0.4655 & Dana alokasi khusus & 86.07 & 0.65069 \\
\hline LBMDSL & 0.537574 & $<.0001$ & & $\begin{array}{l}\text { Belanja modal non pertanian tahun } \\
\text { sebelumnya }\end{array}$ & & \\
\hline Persamaan & elanja Lair & Lain (BLL) & & & & \\
\hline Intercept & 1998.622 & 0.4750 & - & Intercept & & \\
\hline DAU & 0.02877 & 0.2305 & 0.2070 & Dana alokasi umum & & \\
\hline DBH & 0.13045 & 0.1783 & 0.1206 & Dana bagi hasil & 34.24 & 0.49250 \\
\hline PAD & 0.03654 & 0.7395 & 0.0243 & Pendapatan asli daerah & & \\
\hline LBLL & 0.51986 & $<.0001$ & - & Belanja Lain-Lain Tahun sebelumnya & & \\
\hline
\end{tabular}




\section{Kebijakan Fiskal}

Hasil pendugaan model terhadap penerimaan fiskal daerah (Tabel 1) diperoleh bahwa: Pajak daerah dipengaruhi secara nyata dan positif oleh jumlah kamar hotel dan pajak daerah tahun sebelumnya, sementara jumlah kendaraan bermotor dan total pengeluaran pemerintah memiliki tanda positif namun tidak berpengaruh nyata, (2) Retribusi daerah dipengaruhi secara nyata dan positif oleh total pengeluaran pemerintah daerah dan retribusi daerah tahun sebelumnya, sementara PDRB dan jumlah populasi memiliki tanda positif namun tidak berpengaruh nyata, (3) Dana Alokasi Umum (DAU) dipengaruhi secara nyata dan positif oleh jumlah pegawai negeri sipil, luas daerah kabupaten kota, dan jumlah penduduk miskin, dan (4) Dana Bagi Hasil (DAK) dipengaruhi secara nyata dan positif oleh PDRB dan dana bagi hasil tahun sebelumnya.

Hasil pendugaan model terhadap pengeluaran fiskal daerah diperoleh bahwa: (1) Belanja pegawai dipengaruhi secara nyata dan positif oleh jumlah pegawai negeri sipil, pendapatan asli daerah dan belanja pegawai tahun sebelumnya, (2) belanja barang dan jasa dipengaruhi secara positif dan nyata oleh pendapatan asli daerah dan belanja barang dan jasa tahun sebelumnya, sementara dana bagi hasil dan dana alokasi umum memiliki tanda positif, tetapi tidak berpengaruh nyata terhadap belanja barang dan jasa, (3) belanja modal sektor pertanian dipengaruhi secara nyata oleh PDRB sektor pertanian dan belanja modal sektor pertanian tahun sebelumnya, sementara dana alokasi khusus tidak berpengruh nyata, (4) belanja modal non pertanian dipengaruhi secara nyata dan positif oleh dana alokasi khusus, dana bagi hasil dan belanja modal non pertanian tahun sebelumnya, dan (5) belanja lain-lain pemerintah daerah hanya dipengaruhi secara nyata oleh belanja lain-lain tahun sebelumnya, sementara dana alokasi umum, dana bagi hasil, dan pendapatan asli daerah memiliki tanda positif namun tidak berpengaruh nyata.

\section{Permintaan Agregat}

Hasil pendugaan model terhadap permintaan agregat (Tabel 2) diperoleh bahwa, (1) konsumsi masyarakat, dipengaruhi secara nyata oleh Produk Domestik Regional Bruto (PDRB) dan konsumsi masyarakat tahun sebelumnya. Hal tersebut menunjukkan bahwa apabila PDRB dan konsumsi masyarakat tahun sebelumnya meningkat, maka konsumsi masyarakat tahun sebelumnya. Hal tersebut menunjukkan bahwa apabila PDRB dan konsumsi masyarakat tahun sebelumnya meningkat, maka konsumsi masyarakat tahun berjalan akan meningkat (2) Investasi swasta dipengaruhi secara nyata dan positif oleh konsumsi masyarakat dan investasi swasta tahun sebelumnya, namun disisi lain investasi swasta dipengaruhi secara nyata dan negatif terhadap Pendapatan Asli Daerah (PAD). Dengan demikian apabila konsumsi masyarakat dan investasi swasta tahun sebelumnya meningkat, maka investasi swasta tahun berjalan akan meningkat, sebaliknya apabila PAD meningkat, maka investasi swasta akan menurun. Hal ini mengindikasikan bahwa pajak dan retribusi daerah sebagai sumber utama PAD yang dipungut oleh pemerintah daerah mengindikasikan adanya biaya 
ekonomi tinggi (high cost economy), (3) Ekspor daerah dipengaruhi secara nyata dan positif terhadap PDRB dan Ekspor daerah tahun sebelumnya serta dipengaruhi secara nyata dan negatif atas nilai tukar rupiah. Jadi apabila PDRB meningkat dan ekspor daerah tahun sebelumnya meningkat, maka ekspor daerah pada tahun berjalan akan meningkat. Sebaliknya apabila nilai tukar rupiah meningkat, maka ekspor daerah menurun. (4) Impor daerah dipengaruhi secara nyata oleh impor daerah tahun sebelumnya sementara variabel PDRB dan konsumsi, berpengaruh positif namun tidak nyata.

\section{Kinerja Perekonomian}

Hasil pendugaan model terhadap output daerah (Tabel 3), diperoleh bahwa produk domestik regional sektor pertanian hanya dipengaruhi secara positif dan nyata oleh produk domestik regional sektor pertanian tahun sebelumnya, sementara penyerapan tenaga kerja sektor pertanian dan belanja modal sektor pertanian berpengaruh positif namun tidak nyata. Selanjutnya produk domestik regional bruto non pertanian dipengaruhi secara nyata oleh investasi swasta dan produk domestik regional bruto non pertanian tahun sebelumnya, sementara penyerapan tenaga kerja non pertanian dan konsumsi berpengaruh positif namun tidak nyata.

Hasil estimasi model penyerapan tenaga kerja sektor pertanian dan non pertanian menunjukkan bahwa penyerapan tenaga kerja sektor pertanian dipengaruhi secara positif dan nyata oleh jumlah angkatan kerja, dan penyerapan tenaga kerja sektor pertanian tahun sebelumnya, sebaliknya penyerapan tenaga kerja non pertanian berpengaruh negatif dan nyata terhadap penyerapan tenaga kerja sektor pertanian. Kemudian penyerapan tenaga kerja non pertanian dipengaruhi secara positif dan nyata oleh investasi swasta, jumlah angkatan kerja dan penyerapan tenaga kerja non pertanin tahun sebelumnya.

Hasil estimasi model terhadap pengangguran menunjukkan bahwa pengangguran dipengaruhi secara nyata dan positif oleh pengangguran tahun sebelumnya, sedang belanja modal berpengaruh negatif dan nyata terharap pengangguran. Hal tersebut menunjukkan bahwa semakin besar pengangguran tahun sebelumnya, maka tingkat pengangguran tahun berjalan semakin besar, sebaliknya apabila belanja modal ditingkatkan maka pengangguran akan menurun.

Hasil estimasi model terhadap kemiskinan diperoleh bahwa kemiskinan dipengaruhi secara positif dan nyata terhadap jumlah populasi dan jumlah penduduk miskin tahun sebelumnya. Sementara penyerapan tenaga kerja berpengaruh negatif dan nyata terhadap kemiskinan. Kemudian produk domestik regional bruto dan dana dekonsentrasi dan tugas perbantuan, berpengaruh negatif namun tidak nyata.

\section{KESIMPULAN DAN IMPLIKASI KEBIJAKAN}

\section{Kesimpulan}

Hasil penelitian ditemukan bahwa kebijakan fiskal yang dilakukan oleh pemerintah daerah terutama belanja modal sektor pertanian, dapat meningkatkan PDRB sektor pertanain dan pendapatan petani. 
Tabel 2. Hasil Estimasi Parameter Persamaan Permintaan Agregat Daerah

\begin{tabular}{|c|c|c|c|c|c|c|}
\hline \multicolumn{7}{|c|}{ Persamaan Konsumsi Swasta (KONS) } \\
\hline Peubah & Estimasi & Prob $>[\mathrm{T}]$ & Elastisitas & Nama Peubah & F-hitung & $\mathrm{R}^{2}$ \\
\hline Intercept & -53273.7 & 0.0508 & - & Intercept & \multirow{6}{*}{7500,34} & \multirow{6}{*}{0.99636} \\
\hline PDRB & 0.034416 & 0.0556 & 0.0615 & Produk domistik regional bruto & & \\
\hline BBJ & 0.113473 & 0.8969 & 0.0033 & Belanja barang dan jasa & & \\
\hline BPGW & 0.297545 & 0.3536 & 0.0297 & Belanja pegawai & & \\
\hline INFL & 26.27078 & 0.2287 & 0.0205 & Inflasi & & \\
\hline LKONS & 0.99252 & $<.0001$ & & Konsumsi swasta tahun sebelumnya & & \\
\hline \multicolumn{7}{|c|}{ Persamaan Investasi Swasta (INVS) } \\
\hline Intercept & -59462.4 & 0.0120 & - & Intercept & \multirow{5}{*}{1580.57} & \multirow{5}{*}{0.97878} \\
\hline BMD & 0.434145 & 0.2724 & 0.0732 & Belanja modal & & \\
\hline PAD & -4.02862 & 0.0663 & -0.152 & Pendapatan asli daerah & & \\
\hline KONS & 0.154228 & 0.0004 & 0.4566 & Konsumsi swasta & & \\
\hline LINVS & 0.8802 & $<.0001$ & - & Investasi swasta tahun sebelumnya & & \\
\hline \multicolumn{7}{|c|}{ Persamaan Ekspor Daerah (EXPD) } \\
\hline Intercept & 734289 & 0.0127 & - & Intercept & \multirow{5}{*}{5276.89} & \multirow{5}{*}{0.99355} \\
\hline NTRP & -93.3617 & 0.0068 & -1.1132 & Nilai tukar rupiah & & \\
\hline PDRB & 0.152785 & $<.0001$ & 0.3333 & Produk domestik regional bruto & & \\
\hline INFL & 49.19232 & 0.4554 & 0.0476 & Inflasi & & \\
\hline LEXPD & 0.887439 & $<.0001$ & - & Ekspor daerah tahun sebelumnya & & \\
\hline \multicolumn{7}{|c|}{ Persamaan Impor Daerah (IMPD) } \\
\hline Intercept & -28865.7 & 0.2987 & - & Intercept & \multirow{4}{*}{7360,77} & \multirow{4}{*}{0.99383} \\
\hline PDRB & 0.020732 & 0.4749 & 0.0580 & Produk domestik regional bruto & & \\
\hline KONS & 0.003871 & 0.9559 & 0.0061 & Konsumsi swasta & & \\
\hline LIMPD & 1.059737 & $<.0001$ & - & Impor daerah tahun sebelumnya & & \\
\hline
\end{tabular}

Tabel 3. Hasil Estimasi Parameter Persamaan Kinerja Perekonomian

\begin{tabular}{|c|c|c|c|c|c|c|}
\hline \multicolumn{7}{|c|}{ Persamaan PDRB Sektor Pertanian (PDRBSP) } \\
\hline Peubah & Estimasi & Prob $>[T]$ & Elastisitas & Nama Peubah & F-hitung & $\overline{\mathrm{R}^{2}}$ \\
\hline Intercept & -3138.32 & 0.6844 & \multirow{4}{*}{$\begin{array}{l}0.0017 \\
0.0089\end{array}$} & \multirow{4}{*}{$\begin{array}{l}\text { Intercept } \\
\text { Penyerapan T. kerja sektor pertanian } \\
\text { Belanja modal sektor pertanian } \\
\text { PDRBSP tahun sebelumnya }\end{array}$} & \multirow{4}{*}{6445.14} & \multirow{4}{*}{0.9958} \\
\hline PTKSP & 0.013312 & 0.8495 & & & & \\
\hline BMDSP & 0.635525 & 0.5853 & & & & \\
\hline LPDRBSP & 1.034369 & $<.0001$ & & & & \\
\hline \multicolumn{7}{|c|}{ Persamaan PDRB Sektor Tambang (PDRBTB) } \\
\hline Intercept & -20573.3 & 0.0353 & & Intercept & \multirow{5}{*}{60319} & \multirow{5}{*}{0.9994} \\
\hline PTKNP & 0.152716 & 0.5415 & 0.0075 & Penyerapan tenaga kerja non pertanian & & \\
\hline INVS & 0.167825 & $<.0001$ & 0.0455 & Investasi swasta & & \\
\hline KONS & 0.034157 & 0.2182 & 0.0274 & Konsumsi swasta & & \\
\hline LPDRBTB & 1.00702 & $<.0001$ & & PDRB pertambangan tahun sebelumnya & & \\
\hline \multicolumn{7}{|c|}{ Persamaan Penyerapan Tenaga Kerja Sektor Pertanian (PTKSP) } \\
\hline Intercept & -1419.73 & 0.0837 & & Intercept & \multirow{5}{*}{1313.13} & \multirow{5}{*}{0.9891} \\
\hline AKK & 0.743569 & $<.0001$ & 1.5617 & Jumlah angkatan kerja & & \\
\hline INVS & -0.00003 & 0.9865 & -0.0002 & Investasi swasta & & \\
\hline PTKNP & -0.86324 & $<.0001$ & -0.7706 & Penyerapan Tenaga Kerja Non Pertanian & & \\
\hline LPTKSP & 0.232496 & 0.0006 & & PTKSP tahun sebelumnya & & \\
\hline \multicolumn{7}{|c|}{  } \\
\hline Intercept & -586.93 & 0.6865 & & Intercept & \multirow{4}{*}{5205.46} & \multirow{4}{*}{0.9913} \\
\hline INVS & 0.01749 & $<.0001$ & 0.0973 & Investasi swasta & & \\
\hline AKK & 0.05085 & 0.0011 & 0.1196 & Jumlah angkatan kerja & & \\
\hline LPTKNP & 0.84106 & $<.0001$ & & PTKNP tahun sebelumnya & & \\
\hline \multicolumn{7}{|c|}{$\begin{array}{l}\text { Persamaan Pengangguran (UNEP) } \\
\end{array}$} \\
\hline Intercept & 660.4631 & 0.0669 & & Intercept & \multirow{4}{*}{101856} & \multirow{4}{*}{0.9997} \\
\hline AKK & 0.045698 & 0.3627 & 0.4631 & Angkatan kerja & & \\
\hline BMD & -0.03462 & $<.0001$ & -0.1399 & Belanja Modal & & \\
\hline LUNEP & 0.651315 & $<.0001$ & & Pengangguran tahun sebelumnya & & \\
\hline \multicolumn{7}{|c|}{ Persamaan Kemiskinan (MISK) } \\
\hline Intercept & 725.262 & 0.4467 & & Intercept & \multirow{6}{*}{1077.97} & \multirow{6}{*}{0.9692} \\
\hline PDRB & -0.00027 & 0.5764 & -0.0106 & Produk domestik regional bruto & & \\
\hline POP & 0.03295 & 0.0269 & 0.2428 & Jumlah populasi & & \\
\hline PTK & -0.07631 & 0.0162 & -0.2151 & Penyerapan tenaga kerja & & \\
\hline DDTBL & -0.00117 & 0.8107 & -0.0016 & Dana dekonsentrasi, Tugas perbantuan & & \\
\hline LMISK & 0.949714 & $<.0001$ & & Penduduk miskin tahun sebelumnya & & \\
\hline
\end{tabular}


Sementara belanja modal non pertanian dapat mendorong investasi swasta. Selanjutnya investasi swasta dapat mendorong peningkatan produk domestik regional non pertanian. Disamping itu investasi swasta juga dapat menurunkan angka pengangguran. Sementara kemisikinan dapat diturunkan seiring dengan peningkatan produk domestik regional bruto. Pada sisi lain kebijakan fiskal dengan tujuan untuk meningkatkan pendapatan asli daerah dapat mengurangi investasi swasta. Hal ini menunjukkan bahwa apabila pemerintah daerah memaksakan untuk menggali potensi pajak dan retribusi daerah, dapat menimbulkan high cost economy yang berdampak pada turunnya investasi.

\section{Implikasi Kebijakan}

Dengan keterbatasan APBD, maka perlu dilakukan efisiensi penggunaan anggaran terutama pada belanja lain-lain, dan belanja barang dan jasa, selanjutnya digunakan untuk meningkatkan belanja modal untuk memperbaiki infrastrukur yang ada, guna menarik para investor untuk menanamkan modalnya.

Belanja modal sektor pertanian merupakan faktor utama dalam mendorong pertumbuhan PDRB sektor pertanian dan pendapatan petani. Oleh karena itu keberpihakan pemerintah daerah sangat diperlukan dalam pembangunan sektor pertanian dan meningkatkan pendapatan petani, mengingat sebagain besar penduduk kabupaten kota bekerja pada sektor pertanian skala kecil di perdesaan.

\section{DAFTAR PUSTAKA}

Adeniyi, O.M. and A.O. Bashir. 2011. Sectoral Analysis of the Impact of Public Investment on Economic Growth in Nigeria (1970 - 2008). European Journal of Social Sciences, 20(1):259-266.

Darsono. 2008. Analisis Keefektifan Kebijakan Fiskal Terhadap Kinerja Sektor Pertanian Dengan Penekanan pada Agroindustri di Indonesia. Disertasi Doktor. Sekolah Pascasarjana, Institut Pertanian Bogor, Bogor.

Fan, S. and N. Rao. 2003. Public Spending In Developing Countries: Trends, Determination, And Impact. EPTD Discussion Paper No. 99. International Food Policy Research Institute. Washington, D.C.

Feltenstein, A. and S. Iwata (2005). Decentralization and macroeconomic performance in China: regional autonomy has its costs. Journal of Development Economics. 76 (2005) 481- 501.

Guimaraes, R. 2010. What Are The Effects of Fiscal Policy Shocks in India. International Monetary Fund, Amaltas Conference Room Research Meeting, 9-10 March, 2010, India Habitat Centre.

Izuchukwu, O. 2011. Analysis of the Contribution of Agricultural Sector on the Nigerian Economic Development. World Review of Business Research.1(1): 191-200.

Mehmood, R. and S. Sadiq. 2010. The Relationship between Government Expenditure and Poverty: A 
Cointegration Analysis. Romanian Journal of Fiscal Policy. 1(1):29-37.

Nurudeen, A. and A. Usman. 2010.

Government Expenditure And

Economic Growth In Nigeria, 1970-

2008: A Disaggregated Analysis.

Business and Economics Journal, 2010(BEJ-4):1-11.

Priyarsono, D.S., A.Daryanto, dan L.Herliana. 2005. Dapatkah Pertanian Menjadi Mesin Pertumbuhan Ekonomi Indonesia? Analisis Sistem Neraca Sosial Ekonomi. Agro-Ekonomika. 1(35):37-48.

Romer, D. 2001. Advanced macroeconomics, second edition, McGraw-Hill Book Company Co, Singapore.
Sudaryanto, T. dan I. W. Rusastra. 2006. Kebijakan Strategis Usaha Pertanian dalam Rangka Peningkatan Produksi dan Pengentasan Kemiskinan. Jurnal Litbang Pertanian, 25(4);115-122.

World Bank. 2007. Desentralisasi Fiskal dan Kesenjangan Daerah: Kajian Pengeluaran Publik Indonesia 2007. http://siteresources.worldbank.org/I ntindonesia/ Resources/ 2262711168333550999.

Yodhoyono, S.B. 2004. Pembangunan Pertanian dan Perdesaan Sebagai Upaya Mengatasi Kemiskinan dan Pengangguran: Analisisi Ekonomi Politik Kebijakan Fiskal. Disertasi Doktor. Sekolah Pascasarjana, Institut Pertanian Bogor, Bogor

* Dosen STIE dan YPUP (email: akhmad09@yahoo.co.id),

** Dosen Fakultas Ekonomi IPB 
